Proceedings of the $51^{\text {st }}$ Hawaii International Conference on System Sciences | 2018

\title{
Minding the Boundary: Electronic Health Records and the Transformation of U.S. Healthcare Practice
}

\author{
Sean W. Hansen \\ Rochester Institute of Technology \\ shansen@saunders.rit.edu
}

\author{
A. James Baroody \\ Rochester Institute of Technology \\ jbaroody@saunders.rit.edu
}

\begin{abstract}
The U.S. healthcare system is riding a wave of clinical health IT investment, centered on electronic health records (EHR) systems adoption. Supported by governmental incentives, this build-out has positioned the healthcare system for a period of transformation as EHR functionality becomes ingrained in the work routines of healthcare providers and other system participants. We report on a field study of healthcare participants to explore the influence of EHR adoption on the boundaries and practices of the field. Our grounded theory analysis reveals the interplay between the field practices of individual communities and the boundary spanning practices that unite them. Through the adoption of a practice perspective, we assess the varied boundary object aspects of EHR systems and their influence on boundary spanning and field practices alike. We conclude with a consideration of the positive and potentially negative consequences of widespread EHR use for delivery of healthcare services.
\end{abstract}

\section{Introduction}

The healthcare sector in the United States is currently experiencing a rapid growth in the implementation and use of health information technology. Specifically, the U.S. healthcare system has seen an explosion in the adoption of clinical health information technology (HIT). Clinical HIT, which can be differentiated from administrative/financial systems, reflects application software and database platforms that support the delivery of patient care by medical professionals [5]. The form of clinical HIT at the heart of the current adoption boom is the electronic health record (EHR) system, which can be defined as “a repository of patient data in digital form, stored and exchanged securely, and accessible by multiple authorized users” [29: p. 293]. The EHR label is often used interchangeably with electronic medical records (EMR). However, EHR is a broader concept in that it adds the ability of systemic data exchange to EMR's focus on intra-organizational data management [23].
The rapid adoption of EHR systems by healthcare stakeholders has been truly extraordinary. According to the U.S. Office of the National Coordinator for Health IT [47], adoption of at least basic EHR functionality by hospitals hit $83.8 \%$ in 2015 , up from a mere $9.4 \%$ in 2008. This dramatic rate of adoption has largely been driven by governmental efforts. The promotion of clinical HIT has been a point of emphasis in the past two presidential administrations and reflected in multiple recent laws, including the 2009 Health Information Technology for Economic and Clinical Health (HITECH) Act and the 2010 Affordable Care Act (ACA). Aside from merely advocating for clinical HIT adoption, the HITECH Act explicitly incentivized EHR adoption and use. The foundation for this governmental promotion is a wide range of purported benefits engendered by EHR technology, including enhanced continuity of care [30], reduction of medical errors [52], greater accuracy of patient documentation [58], and broad quality of care improvements [44].

The heterogeneous nature of the U.S. healthcare system presents a number of opportunities and challenges vis-à-vis clinical HIT adoption and use. The field is marked by the interaction of individuals and organizations with diverse practices, interests, and areas of focus [12, 17]. In addition to the patients, prominent healthcare system stakeholders include primary care physicians, specialist physicians, other clinicians and lab services, hospitals, long-term care facilities, payers (e.g., insurance providers, Medicare and Medicaid programs), credentialing bodies, and multiple regulatory entities.

Interestingly, the diversity of healthcare system players has been one of the primary factors underlying arguments for the necessity of EHR platform adoption $[10,31]$. The motivating vision has been that clinical HIT - and particularly EHR systems - can help to bridge the boundaries between the diverse health system actors and organizations [6]. In light of significant adoption in recent years, it is an appropriate time to assess the degree to which that bridging vision has been brought to fruition. In the present study, we build upon the extensive study of boundary spanning and boundary objects within the information systems (IS) field to explore the impacts of EHR systems on stakeholder interactions in the U.S. healthcare system. 
Specifically, we seek to address the following research questions:

- How do EHR systems impact boundary spanning practices within the U.S. healthcare system?

- What are the impacts to practices within professional fields with the broad introduction of EHR systems?

In developing this exploration, we first provide a brief introduction to the U.S. healthcare system, with an emphasis on prominent stakeholder groups and significant trends. We follow this with an overview of research on boundary spanning and boundary objects, with a specific emphasis on their application in the IS domain. We then present our research methodology before moving to a delineation of findings. Our subsequent discussion focuses on the key implications from the research from theoretical and practical perspectives. Finally, we conclude with the essential insights from the research.

\section{Clinical HIT in US Healthcare}

The healthcare system has been a consistent feature of social and political discourse in the U.S. for several years. Much of the coverage of the sector has centered on the rapid rise in healthcare costs, which are not accompanied by commensurate improvements in healthcare outcomes [22, 56]. To address this discrepancy, several market observers have highlighted the potential for increased use of HIT to enhance process efficiency, improve patient safety, and generally augment quality of care [13, 31].

One of the essential features of the U.S. healthcare system is its tremendous heterogeneity. The sector is marked by the continual interaction of a wide array of stakeholder groups, including patients, healthcare service providers (e.g., primary care physicians, specialists, nurses), hospitals and long-term care facilities, laboratories, insurance companies and governmental payers (e.g., Medicare and Medicaid), federal and state regulators, and credentialing entities. Given the complexity of this system, the benefits of clinical HIT are likely to be contingent upon the degree to which such tools enhance health information exchange (HIE) among the diverse organizations and roles within the field [59].

In recent years, several legislative efforts have been initiated to foster such exchange. Most notably, in 2009, the Health Information Technology for Economic and Clinical Health (HITECH) Act created a strong impetus for improving healthcare delivery through significant investments in IT [7]. Specifically, the HITECH Act allocated \$19 billion in funding for the adoption of clinical IT, aiming for the adoption of a comprehensive EHR by $90 \%$ of physicians' offices and $70 \%$ of hospitals by 2019 . The law outlines regulatory expectations for the "meaningful use" of EHR technology, with a series of guidelines for escalating functionality and application [14]. Importantly, this meaningful use program incorporates a set of incentives to promote EHR use. Prior to 2016, the program offered providers a subsidy to offset the cost of EHR investment - $\$ 44,000$ to $\$ 64,000$ for physicians' practices and $\$ 2$ million or more for hospitals. Beginning in 2016, a "penalty" phase was introduced, with providers incurring reduced Medicare and Medicaid reimbursements for failing to comply with meaningful use requirements.

As noted above, one of the primary objectives underlying all of these legislative and regulatory efforts is the enhancement of information exchange [59]. The HITECH Act mandates that EHR platforms be "connected in a manner that provides ... for the electronic exchange of health information to improve the quality of health care, such as promoting care coordination" (p. 356). The fragmentation of health information across diverse systems and business units is regularly cited as a primary factor undermining efficiency, impairing coordination of care, and driving up costs in the U.S. healthcare system [59]. Thus, the vision of meaningful use is one of interoperability [1].

With the increased adoption of EHR systems in the United States, studies of observed benefits have begun to emerge. Drawing upon two national surveys on physicians' view of EHR technology, King et al. [35] highlight clinical benefits related to information availability, alerts for potential medication errors, and reduction in redundant lab tests. Zlabek et al. [61] report similar benefits in analysis of data before and after the implementation of an EHR at a communitybased teaching hospital. Finally, Menachemi and Brooks [43] assess the return on investment for clinical HIT through a focused examination of different functionality, such as a common patient record, computerized physician order entry (CPOE) and clinical decision support systems (CDSS). They trace a series of benefits in the areas of increased revenues, averted costs, and less tangible measures (e.g., patient safety, coordination to care).

\section{Boundary Spanning and Boundary Objects}

Boundaries are a natural consequence of all organizational action. As individuals and groups within an organization or institutional setting development local behavioral norms, they are differentiated from the external environment which adopts or espouses distinct practices [38, 42]. As Leifer and Delbecq [37] observe, 
a boundary represents "the demarcation line or region between one system and another, that protects the members of the system from extra-systemic influences and that regulates the flow of information, material, and people into or out of the system” (p. 41). Thus, a boundary defines the limits of a group, enabling the distinction between those who are members of the group and those who are not $[4,50]$. Organizations or professional categories are generally designed to exploit the benefits of specialization and internal knowledge exchange that accompanies with this demarcation [36, 45].

At the same time, boundaries create barriers to communication and learning between groups and with the external environment [16, 20, 57]. In light of this challenge, an extensive research literature has been developed around the importance of boundary spanning practices for enabling an organization to interpret its environment and learn from the collective experiences of its members [e.g., 37, 38, 57].

Much of the early treatment of boundary spanning focused on the importance of boundary spanners, individuals who function at the boundary of two or more groups and enable the flow of information across those boundaries [36, 57]. The fostering of boundary spanning roles was identified as a critical enabler of organizational innovation, enabling groups to integrate knowledge from their environment [11, 40].

Later work focused on the principle of the boundary object - i.e., a material or conceptual artifact that creates a communicative bridge between distinct social groups [53, 54]. This bridging function is achieved because boundary objects reside within each (or all) of the separate contexts of interest, where they can be adapted to local uses while still maintaining a universal identity: "[Boundary objects] have different meanings in different social worlds but their structure is common enough to more than one world to make them recognizable, a means of translation" [54: p. 393]. Adapting the typology first proposed by Star and Griesemer [54], Carlile [9] identifies multiple prominent types of boundary objects, including repositories (e.g., databases, libraries), ideal types (e.g., map or atlas), standardized forms and methods (e.g., reporting forms or procedures), objects/models (e.g., prototypes, design drawings), and maps of coincident boundaries (e.g., process maps, Gantt charts).

In light of these examples, it is perhaps not surprising that the boundary object concept has been widely applied by the IS research community to the role of IT in collaborative undertakings [21, 28, 32, 38]. Multiple researchers have considered the boundary object role of enterprise information systems, such as enterprise resource planning (ERP) platforms [27, 33, 49]. The concept has similarly been applied to objects employed in IS development processes, including the boundary spanning value of prototypes and design documentation $[15,26]$.

An important sub-theme within the analysis of boundary objects is the emergence of what has been called a "practice perspective" [38, 48]. Building upon the exploration of the interplay between social structures and human agency by sociologists such as Bourdieu [8] and Giddens [24], the practice perspective places a premium on how boundary spanning practices and boundary objects are created and evolve in the lived experience of organizational actors, rather than in an idealized procedural understanding [48]. Levina and Vaast [38] accentuate the importance of boundary spanners-in-practice interacting with boundary objects-in-use to create new joint fields that enable exchange. In subsequent work, Levina and Vaast [39] highlight how IT resources may be used to engender less relationally grounded and more market-like practices through a process of objectification. Kellogg et al. [34] identify a range of practices and artifacts that emerge in the boundary spanning efforts of social actors in non-hierarchical organization. At the industry level, Zietsma and Lawrence [60] develop the recursive relationship between boundaries and practices that emerge across an entire field. Several other studies [e.g., 3, 40, 41, 51] have similarly adopted an emphasis on the interplay of boundary spanning and boundary objects in the observed practices of individuals and groups.

\section{Research Method}

To explore the current state of clinical IT use and its boundary spanning implications, we conducted a qualitative field study and interpretive analysis focusing on the experiences of stakeholders regarding the implementation and use of EHR functionality.

\subsection{Data Collection}

In the study, we employed two central mechanisms of data collection - interviewing and documentary review. The primary mode of data collection in the study was interviewing. Specifically, we conducted a series of 26 semi-structured interviews with diverse professionals in and around the U.S. healthcare system. In light of the aforementioned heterogeneity of the healthcare field, we sought participation from individuals and firms engaged in a variety of healthcare-oriented environments. These included multiple clinicians (8), healthcare IT managers (9), healthcare executives and payers (7), and health information intermediaries (2). The identification of respondents was based on a "snowball sampling" 
technique (i.e., using initial respondents within each stakeholder group to identify other possible respondents for inclusion in the study) [46]. The interviews ranged in duration from 60 to 100 minutes. In an effort to avoid concerns over patient privacy and the protection of sensitive information, we did not pursue interviews with patients.

All interviews were conducted using an interview protocol designed to foster respondents' reflection upon their experiences with the use of clinical HIT systems as well as healthcare service delivery. Specific facets outlined in the interview protocol included approaches to HIT implementation, drivers for HIT adoption, systems integration objectives, organizational challenges, and approaches to collaboration with other healthcare stakeholders. In keeping with the principle of constant comparison [25], questions were periodically added to the protocol based on insights from earlier interview. Outside of the structured protocol, respondents were encouraged to reflect or comment on any issues they felt were relevant regarding the adoption and use of HIT and HIE in healthcare settings.

A secondary data set was also collected and analyzed as part of the study. Specifically, we identified policy documents and published reports highlighting federal and state regulatory initiatives around HIT adoption. These secondary sources were deemed relevant, because they articulate objectives and envisioned mechanisms for creating a more integrated healthcare system through the use of clinical HIT.

\subsection{Data Analysis}

All interviews were transcribed for formal data analysis. Interview transcripts and external sources were coded using NVivo, a qualitative analysis application. Data analysis was conducted through multiple waves of coding. In the initial coding efforts, the interview protocol was used as a preliminary coding structure for the data. Additional codes were created as themes or recurring issues were identified. The coding was conducted in line with key principles of grounded theory methodology [25, 55], such as constant comparison and open, axial, and selective coding. The code structure was iteratively revised until the researchers determined that all relevant themes were reflected [18]. The transcripts and other source documents were coded repeatedly as the final coding structure emerged. The objective of this analysis was to identify communities of practice that are relevant to the adoption and use of clinical HIT systems and the distinct practices that are enabled or mediated by the use of such systems. Accordingly, the initial round of coding focused on the identification of prominent communities/stakeholder groups, the practices in which they engage, and the degree to which these practices have been influenced by the use of clinical HIT such as EHR platforms.

A second round of coding focused on the relationship between themes identified in the initial phase. In a particular, we assessed the degree to which practices identified were related to what Zietsma and Lawrence [60] refer to as boundary work - efforts aimed at the maintenance, reinforcement, undermining, or spanning of the boundaries between the communities of practice identified. Such boundary work can be distinguished from field practices (i.e., what Zietsma and Lawrence [60] referred to simply as "practices") - the shared routines that define work within the relevant community. In a final round of coding, we focused on the changes in practice whether boundary work or field practices - and its association with the clinical HIT systems in use.

\section{Findings}

Our analysis revealed a number of insights regarding the interaction of field and boundary practices within the healthcare system and how they are impacted by the use of EHR technologies. We first highlight the prominent communities and their field practices.

\subsection{Communities, Field Practices, and Boundaries}

In light of the heterogeneous nature of the field, we see evidence of multiple stakeholder groups, or communities, interacting in the reflections of our participants. While we note the role of the patients as one of the critical stakeholder groups in the healthcare system (one could argue, of course, that they are the ultimate stakeholder group), we focus our analysis primarily on the organizational actors in the system to emphasize the work practices reflected and to avoid concerns over patient privacy and the protection of sensitive information. For each of the professional communities identified we highlight the central field practices in which they engage. The prominent communities reflected in the analysis are summarized in Table 1:

Table 1. Communities and Field Practices

\begin{tabular}{|l|l|l|}
\hline \multicolumn{1}{|c|}{ Community } & \multicolumn{1}{|c|}{ Description } & \multicolumn{1}{|c|}{$\begin{array}{l}\text { Key Field } \\
\text { Practices }\end{array}$} \\
\hline $\begin{array}{l}\text { Healthcare } \\
\text { Providers }\end{array}$ & $\begin{array}{l}\text { Render services to } \\
\text { improve patient health; } \\
\text { e.g., physicians, nurses. }\end{array}$ & $\begin{array}{l}\text { Patient care; } \\
\text { treatment plan } \\
\text { dev.; research }\end{array}$ \\
\hline
\end{tabular}




\begin{tabular}{|l|l|l|}
\hline \multicolumn{3}{|c|}{ Table 1. Communities and Field Practices } \\
\hline Community & \multicolumn{1}{|c|}{ Description } & \multicolumn{1}{c|}{$\begin{array}{l}\text { Key Field } \\
\text { Practices }\end{array}$} \\
\hline $\begin{array}{l}\text { Health } \\
\text { Technicians }\end{array}$ & $\begin{array}{l}\text { Deliver ancillary } \\
\text { services and } \\
\text { diagnostics; e.g., } \\
\text { radiologists, lab } \\
\text { technicians. }\end{array}$ & $\begin{array}{l}\text { Diagnostic } \\
\text { testing and } \\
\text { analysis; health } \\
\text { imaging }\end{array}$ \\
\hline $\begin{array}{l}\text { Healthcare } \\
\text { Admins. }\end{array}$ & $\begin{array}{l}\text { Direct financial/ } \\
\text { strategic action of } \\
\text { health orgs.; e.g., hosp. } \\
\text { admins., practice mgrs.. }\end{array}$ & $\begin{array}{l}\text { Billing; ordering; } \\
\text { fin. mgmt.; HR } \\
\text { mgmt.; data } \\
\text { analysis }\end{array}$ \\
\hline $\begin{array}{l}\text { Health IT } \\
\text { manage- }\end{array}$ & $\begin{array}{l}\text { Manage implem. and } \\
\text { support of HIT } \\
\text { resources; e.g., hosp. IT } \\
\text { directors, CTOs }\end{array}$ & $\begin{array}{l}\text { Syst. maint;; } \\
\text { implem./project } \\
\text { mgmt.; security } \\
\text { mgmt.. }\end{array}$ \\
\hline Payers & $\begin{array}{l}\text { Insurance firms and } \\
\text { gov. paying entities } \\
\text { (e.g., Medicaid, } \\
\text { Medicare) }\end{array}$ & $\begin{array}{l}\text { Underwriting; } \\
\text { data analysis; } \\
\text { fraud prev.; } \\
\text { reimbursement }\end{array}$ \\
\hline $\begin{array}{l}\text { Regulatory } \\
\text { entities }\end{array}$ & $\begin{array}{l}\text { Regulatory bodies and } \\
\text { credentialing entities; } \\
\text { e.g., HHS, state health } \\
\text { depts., JCAHO }\end{array}$ & $\begin{array}{l}\text { Policy setting; } \\
\text { data analysis; } \\
\text { provider } \\
\text { evaluation }\end{array}$ \\
\hline
\end{tabular}

\subsection{Boundary Spanning Practices}

In light of heterogeneity of the field, the demands of boundary spanning are significant. Indeed, amongst our respondents, the importance of boundary spanning was consistently underscored. Specifically, respondents remarked on efforts to improve information exchange between distinct professional categories (e.g., nurses, primary care physicians, specialty physicians, and administrators). Similarly, respondents discussed boundary spanning across distinct business units (e.g., clinical departments, labs, and hospital billing). At the level of the healthcare system, an emphasis on boundary spanning is seen in the drive for integration of data across organization types, such as providers (e.g., physicians, hospitals), insurance payers, and regulators.

With respect to the use of EHR technologies, the healthcare providers are the central players in the interactions that define the field. Indeed, the providers engage in boundary spanning work with each of the other communities as well as across boundaries of specialty or professional distinction. In each case, this boundary work is transformed through the use of specific EHR-based functionality. The EHR technologies are largely mediating the healthcare providers' exchanges with all of the other communities. The following statements illustrate this observation:
"Everything has to work together. So, we see on the clinical side for example, there's a great relationship between CPOE, pharmacy, medication administration, nursing, clinical care, and order management. That's all tightly integrated ... Everybody's got to do that together because the left hand has to know what the right hand's doing." - Hospital System IT Director 2

"I would see integration as ... how those three layers the physician aspect, the nursing aspect, and the front staff/billing aspect - exchange information. The data would have to flow through all three of those layers; both from physician down and from billing up, and the data would need to be able to move through all three groups." - Health Service Provider 2

The distinct boundaries identified, as well the key boundary spanning practices associated with them, are outlined in Table 2.

\begin{tabular}{|c|c|c|}
\hline \multicolumn{3}{|c|}{ Table 2. Boundary Spanning Practices } \\
\hline Boundary & $\begin{array}{l}\text { Boundary } \\
\text { Practices }\end{array}$ & $\begin{array}{l}\text { Relevant EHR } \\
\text { Elements }\end{array}$ \\
\hline $\begin{array}{l}\text { Patient- } \\
\text { Provider }\end{array}$ & $\begin{array}{l}\text { Patient } \\
\text { consultations }\end{array}$ & $\begin{array}{l}\text { Record capture; } \\
\text { Patient portals }\end{array}$ \\
\hline \multirow[t]{3}{*}{$\begin{array}{l}\text { Provider- } \\
\text { Provider }\end{array}$} & $\begin{array}{l}\text { Phys. ordering/ } \\
\text { Referral }\end{array}$ & $\begin{array}{l}\text { CPOE/Referral } \\
\text { modules }\end{array}$ \\
\hline & Charting & Clinical history \\
\hline & $\begin{array}{l}\text { Medication } \\
\text { Management }\end{array}$ & ePrescription \\
\hline $\begin{array}{l}\text { Provider- } \\
\text { Technician }\end{array}$ & $\begin{array}{l}\text { Physician } \\
\text { ordering }\end{array}$ & CPOE \\
\hline \multirow{3}{*}{$\begin{array}{l}\text { Provider- } \\
\text { Health } \\
\text { Admins. }\end{array}$} & $\begin{array}{l}\text { Point-of-care } \\
\text { admin. }\end{array}$ & $\begin{array}{l}\text { Scheduling; } \\
\text { Clinical history }\end{array}$ \\
\hline & $\begin{array}{l}\text { Cash flow } \\
\text { management }\end{array}$ & Billing system \\
\hline & $\begin{array}{l}\text { Production } \\
\text { management }\end{array}$ & $\begin{array}{l}\text { Scheduling; } \\
\text { Dashboards }\end{array}$ \\
\hline \multirow{2}{*}{$\begin{array}{l}\text { Provider- } \\
\text { Health IT } \\
\text { Management }\end{array}$} & Training & All elements \\
\hline & $\begin{array}{l}\text { System } \\
\text { enhancement }\end{array}$ & All elements \\
\hline \multirow[t]{2}{*}{$\begin{array}{l}\text { Provider- } \\
\text { Payer }\end{array}$} & $\begin{array}{l}\text { Billing \& } \\
\text { Reimbursement }\end{array}$ & Billing system \\
\hline & Reporting & $\begin{array}{l}\text { Data analysis and } \\
\text { reporting }\end{array}$ \\
\hline $\begin{array}{l}\text { Provider- } \\
\text { Regulators }\end{array}$ & $\begin{array}{l}\text { Regulatory } \\
\text { reporting }\end{array}$ & $\begin{array}{l}\text { Data analysis and } \\
\text { reporting }\end{array}$ \\
\hline
\end{tabular}

In analyzing the impact of EHR systems, it is tempting to identify the platforms broadly as the increasingly central boundary objects in the healthcare field. And, indeed, EHR systems can be understood to represent the repository form of a boundary object [9, 
54]. However, the adoption of a practice perspective and a corresponding focus on the ways in which EHR functionality influences individual boundary spanning practices - suggests that a monolithic view of EHR platforms could be problematic. Based on our analysis, we contend that EHR systems are better understood as bundles of diverse boundary objects. Each of the community boundaries, and the associated boundary spanning efforts, are influenced by separate modules of the EHR systems, such as scheduling, charting, billing, and reporting. In many ways, the rapid adoption of these new sets of tools has resulted in welcome enhancements to boundary spanning efforts. For example, some efficiency gains are palpable:

"Well, it's not easy to document and pull information from a paper chart. If I put it down on paper, it's locked there. So if someone comes with forms, there are offices that are charging to fill out forms. If it's electronic, that's fine. Click, click, done. I think that saves some time. So once you do that investment in documentation, that part that they hate, long-term they see the benefit of it." Health Service Provider / Health IT Consultant

However, our respondents' comments suggest that not all the changes to boundary spanning efforts in the wake of EHR adoption have been beneficial. They called attention to a number of changes which were perceived to adversely impact information exchange within the healthcare system. These perceptions were especially noteworthy among the healthcare providers. Key elements noted include the following:

Table 3. Boundary Spanning Challenges

\begin{tabular}{|c|c|c|}
\hline Perception & Description & Illustrative Statement \\
\hline $\begin{array}{l}\text { Commun- } \\
\text { ication } \\
\text { Quality }\end{array}$ & $\begin{array}{l}\text { Communication } \\
\text { enabled by EHR } \\
\text { systems } \\
\text { perceived as } \\
\text { inferior to face- } \\
\text { to-face and } \\
\text { paper-based } \\
\text { methods }\end{array}$ & $\begin{array}{l}\text { "This whole business } \\
\text { about electronic health } \\
\text { records helping with } \\
\text { communication I think } \\
\text { is a total fallacy. I think } \\
\text { it really hinders } \\
\text { communication." - } \\
\text { Health Provider } 2\end{array}$ \\
\hline $\begin{array}{l}\text { Usability } \\
\text { and } \\
\text { Techno- } \\
\text { centrism }\end{array}$ & $\begin{array}{l}\text { Perception that } \\
\text { EHRs may } \\
\text { increase the } \\
\text { likelihood of } \\
\text { errors because } \\
\text { of technology- } \\
\text { oriented input. }\end{array}$ & $\begin{array}{l}\text { "Sometimes I'll enter } \\
\text { the wrong [procedure], } \\
\text { even though I know } \\
\text { what I want and I think } \\
\text { I'm ordering the right } \\
\text { one ... but I don't know } \\
\text { which choice in the } \\
\text { computer to choose." - } \\
\text { Healthcare Provider } 8\end{array}$ \\
\hline $\begin{array}{l}\text { Design } \\
\text { Bias }\end{array}$ & $\begin{array}{l}\text { Belief that } \\
\text { EHRs change } \\
\text { the power } \\
\text { balance between }\end{array}$ & $\begin{array}{l}\text { "We're being pushed by } \\
\text { the government, and the } \\
\text { insurance companies, } \\
\text { and the payers... It's }\end{array}$ \\
\hline
\end{tabular}

\begin{tabular}{|c|c|c|}
\hline & communities & $\begin{array}{l}\text { not for us, it's for } \\
\text { them." - Healthcare } \\
\text { Provider } 1\end{array}$ \\
\hline $\begin{array}{l}\text { Adverse } \\
\text { Incentives }\end{array}$ & $\begin{array}{l}\text { Possibility that } \\
\text { EHRs may } \\
\text { increase } \\
\text { likelihood of } \\
\text { entities taking } \\
\text { actions that do } \\
\text { not improve } \\
\text { service delivery }\end{array}$ & $\begin{array}{l}\text { "Sometimes... I'll go } \\
\text { back see if there was } \\
\text { anything else that I } \\
\text { forgot to document that } \\
\text { would get me to a } \\
\text { higher level visit.' I } \\
\text { don't feel like it's to do } \\
\text { better for the patient. I } \\
\text { feel like it's to generate } \\
\text { more revenue." - } \\
\text { Healthcare Provider } 8\end{array}$ \\
\hline $\begin{array}{l}\text { Reduced } \\
\text { flexibility }\end{array}$ & $\begin{array}{l}\text { Concern that } \\
\text { EHR systems } \\
\text { (and associated } \\
\text { regulatory } \\
\text { mandates) } \\
\text { reduce provider } \\
\text { choice and } \\
\text { discretion }\end{array}$ & $\begin{array}{l}\text { "We have a homegrown } \\
\text { medication records } \\
\text { reconciliation system. It } \\
\text { worked very well ... But } \\
\text { we can't use our } \\
\text { homegrown system." - } \\
\text { Rural Hospital IT } \\
\text { Director } 1\end{array}$ \\
\hline
\end{tabular}

Thus, by considering the diversity of boundary objects embedded within EHR platforms we may be better positioned to evaluate the impact on boundary spanning practices. However, it is interesting to note that the impact of EHR technology is not limited to efforts at the boundaries.

\subsection{EHR Impacts on Field Practices}

One of the critical observations in our study is that the boundary spanning influence of EHR technologies has ripple effects into the field practices of stakeholder communities. Much of the public policy discourse and argumentation around EHR adoption has focused on the boundary spanning enhancements that the technology offers. But our respondents reflected on the range of changes to their day-to-day activities that are impacted by these systems. In Table 4, we summarize a number of significant changes to field practices engendered by EHR adoption and use. We provide exemplary statements from our study respondents to illustrate the proposed changes:

\begin{tabular}{|l|l|l|}
\hline \multicolumn{3}{|c|}{ Table 4. EHR Impacts on Field Practices } \\
\hline $\begin{array}{c}\text { Field } \\
\text { Practices }\end{array}$ & \multicolumn{1}{|c|}{ Changes } & \multicolumn{1}{c|}{ Illustrative Statements } \\
\hline $\begin{array}{l}\text { Patient } \\
\text { Care }\end{array}$ & $\begin{array}{l}\text { Changing } \\
\text { ways in } \\
\text { which } \\
\text { clinicians } \\
\text { render care }\end{array}$ & $\begin{array}{l}\text { "I think we do every now, and } \\
\text { then realize that we just spend a } \\
\text { lot of time not caring for } \\
\text { patients in way that we perceive } \\
\text { as a traditional way of caring } \\
\text { for patients." - Healthcare } \\
\text { Provider 7 }\end{array}$ \\
\hline
\end{tabular}




\begin{tabular}{|l|l|l|}
\hline $\begin{array}{l}\text { Treatment } \\
\text { plan devel. }\end{array}$ & $\begin{array}{l}\text { Creating a } \\
\text { data-driven } \\
\text { approach to } \\
\text { plan devel. }\end{array}$ & $\begin{array}{l}\text { "Why not make data available } \\
\text { to physicians ... and see what's } \\
\text { working? I would love to see } \\
\text { that, in the organization and in } \\
\text { the communities, back on data } \\
\text { to help us be smarter." - } \\
\text { Healthcare Provider 5 }\end{array}$ \\
\hline $\begin{array}{l}\text { Practice } \\
\text { Admin. }\end{array}$ & $\begin{array}{l}\text { Changing } \\
\text { work } \\
\text { patterns } \\
\text { around } \\
\text { documenta- } \\
\text { tion of } \\
\text { work }\end{array}$ & $\begin{array}{l}\text { "I couldn't type much in the } \\
\text { visits, so I would leave the } \\
\text { room, leave the encounter with } \\
\text { the patient having all of my } \\
\text { charting to do. So I would make } \\
\text { a few notes... and then the rest } \\
\text { of the visit in the computer } \\
\text { would be left until after hours." } \\
\text { - Healthcare Provider } 8\end{array}$ \\
\hline $\begin{array}{l}\text { Financial } \\
\text { Mgmt. }\end{array}$ & $\begin{array}{l}\text { Altering } \\
\text { approaches } \\
\text { to revenue } \\
\text { generation } \\
\text { and cost } \\
\text { control }\end{array}$ & $\begin{array}{l}\text { "[The EHR] tells you from what } \\
\text { you have done and what you } \\
\text { have clicked on, what you're } \\
\text { eligible to bill for ... If you click } \\
\text { on the right number of things, } \\
\text { our system actually enters the } \\
\text { billing for you." - Healthcare } \\
\text { Provider } 8\end{array}$ \\
\hline $\begin{array}{l}\text { Data } \\
\text { Analysis }\end{array}$ & $\begin{array}{l}\text { Expanding } \\
\text { evidence } \\
\text { base for } \\
\text { decision- } \\
\text { making }\end{array}$ & $\begin{array}{l}\text { "We did a deeper dive on all } \\
\text { other benefits including } \\
\text { patient's safety, medication } \\
\text { errors, length of stay analysis ... } \\
\text { That's just one of the benefits." } \\
\text { - Healthcare Provider 4 }\end{array}$ \\
\hline
\end{tabular}

\section{Discussion}

As a field, healthcare can be distinguished by the significance that it holds for every member of a society. Sooner or later each of us relies upon the many communities that make up the healthcare system to provide the services we need to enjoy a long and healthy life. Accordingly, we all have a vested interest in the changes that are shaping the field through the rapid adoption of EHR and other clinical IT systems. Based on our analysis, we contend that there are a number of questions that warrant more explicit consideration in social and public policy discourses.

Our study highlights several changes - to both boundary spanning and field practices - engendered by EHR adoption. Therefore, it is relevant to ask whether or not these changes are desirable or conducive to an enhanced system of healthcare delivery.

With respect to boundary spanning practices, the extant research suggests that EHR has transformed a number of outdated (often paper-based) exchange practices and increased overall healthcare system efficiency. However, our findings imply that the benefits may be unequally distributed across boundaries. To a significant extent, healthcare service providers perceive that the payers and regulatory entities reap the greatest reward because of the increased codification of services. Indeed, on the question of efficiency, they argue that EHR technology increases the efficiency of claims processing and regulatory enforcement, but that it undermines the efficiency of treating patients by adding work steps and reducing the interpretability of patient records. Similarly, respondents argued that EHR platforms may at times increase the incidence of errors or even fraud because of usability concerns and adverse incentives (i.e., promoting “click"-based reimbursement padding). These challenges are augmented by the requirement for federal certification of EHR systems in meaningful use regulations, limiting the discretion of healthcare providers in selecting or customizing EHR tools.

Interestingly, EHR adoption has not only changed the boundary spanning practices of communities; it has changed their visibility to other communities within the system. For example, much of the boundary spanning that occurred when patient records were on paper was not visible to the patient. The introduction of EHR interfaces (esp. patient portals) makes more of this boundary spanning visible to the patient through provider review of the patient's record during care and through the provider entering information into the patient's chart and into billing and regulatory forms while the patient is present.

While the rhetoric around EHR adoption has focused largely on the boundary spanning that it enables, some of the most substantive changes engendered are to the field practices of healthcare service providers. Here again, the picture is mixed. Some clear improvements can be identified in areas such as enhanced decision support through data analysis and the automation of labor intensive practices. However, other field practice changes are less favorable. Most notably, the delivery of care is impacted by the impetus to enter data into the EHR systems in real-time. The fear of a depersonalized doctor-patient relationship is shared by patients and service providers alike.

The shift in field practices that we observe raises the question of whether the adoption of EHR tools has fundamentally shifted the boundaries between communities and the nature of the communities themselves. The prominent critique that these technologies have "turned physicians into data entry clerks" [19] is indicative of this concern. By shifting boundaries and transferring selected field practices from one community to another, EHR technologies may be reshaping healthcare communities in unanticipated and undesirable ways.

Finally, as we have noted, it is dangerous to conceptualize EHR systems as undifferentiated 
boundary objects. Rather, EHR platforms represent diverse sets of boundary objects centered around bundles of functionality. Distinguishing between modules that support boundary spanning practices and those that inhibit or undermine such practices will be critical in the design of the next generation of EHR systems. The American Medical Association [2] has recently called for a fundamental redesign of EHR systems, with an eye to provider and patient usability. Such redesign efforts will need to be informed by current experiences at the boundaries within the healthcare system.

The adjudication of these questions is certainly beyond the scope of the present analysis. Indeed, the ultimate impact of EHR adoption is likely to occupy the field for many years. Our purpose is merely to call attention to the multi-faceted nature of the changes in practice engendered by EHR. In particular, we argue that these types of questions should be consistently explored as public policy continues to promote the adoption of such systems. At the same time, observations regarding the practice-oriented impacts of EHR can be used to foster platform re-design efforts with an eye to enhancing favorable practice changes and mitigating potentially problematic ones.

\section{Conclusion}

In this study, we have explored the impact of EHR system adoption and use on the field and boundary spanning practices that define the U.S. healthcare system. The past few years have been marked by an unprecedented pace of adoption for these clinical HIT resources and their influence on the interactions of healthcare's heterogeneous communities is just beginning to emerge. Our analysis highlights the dramatic scope of boundary spanning efforts within the healthcare domain and the interplay between the field practices of individual communities and the boundary spanning practices that unite them. In addition, we highlight the degree to which these boundary spanning activities are mediated by EHR software platforms. Rather than viewing EHR systems as boundary objects in a monolithic fashion, we argue that EHR technologies represent bundles of boundary objects, with distinct modules or elements enabling boundary spanning at various boundaries between healthcare providers and their system collaborators. The introduction of these boundary object components has effectively transformed the boundary spanning practices of communities. Some of these changes are met with trepidation by participants in the healthcare system. Finally, we argue that the boundary object effects of EHR technologies are not limited to boundary spanning activities; rather, they extend also to the field practices of the communities involved.

There are a number of key contributions from this study which we wish to highlight. First, the study delineates both the range of boundary spanning practices that mark the contemporary U.S. healthcare system and the influence that EHR adoption has had on those practices. Second, through the adoption of a practice perspective, we move beyond a broad-brush characterization of EHRs as boundary objects to delve into variety of boundary object effects embedded within these emergent platforms. Finally, the study underscores the ways in which boundary objects can influence not only the boundary spanning practices of various communities but also the field practices which set them apart. The U.S. healthcare system is at the brink of a period of tremendous change and transformation as EHR technologies become more ingrained in the work routines of healthcare providers and other system participants. As healthcare stakeholders, we all have a vested interest in assessing the benefits - and addressing the shortcomings - that emerge as that transformation takes shape.

\section{References}

[1] J. Adler-Milstein, et al., "Operational health information exchanges show substantial growth, but long-term funding remains a concern," Health Affairs, vol. 32, pp. 1486-1492, 2013.

[2] AMA, "AMA Calls for Design Overhaul of Electronic Health Records to Improve Usability," American Medical Association, Chicago, ILSeptember 162014.

[3] M. Barrett, et al., "Reconfiguring boundary relations: Robotic innovations in pharmacy work," Organization Science, vol. 23, pp. 1448-1466, 2012.

[4] C. A. Bartel, "Social comparisons in boundary-spanning work: Effects of community outreach on members' organizational identity and identification," Administrative Science Quarterly, vol. 46, pp. 379-413, 2001.

[5] B. I. Blum, Clinical Information Systems. Berlin, Germany: Springer-Verlag, 2013.

[6] D. Blumenthal, "Implementation of the federal health information technology initiative," New England Journal of Medicine, vol. 365, pp. 2426-2431, 2011.

[7] D. Blumenthal and M. Tavenner, "The "Meaningful Use” Regulation for Electronic Health Records," New England Journal of Medicine, vol. 363, pp. 501-504, 2010.

[8] P. Bourdieu, Outline of a Theory of Practice vol. 16. Cambridge, UK: Cambridge University Press, 1977. 
[9] P. R. Carlile, "A pragmatic view of knowledge and boundaries: Boundary objects in new product development," Organization Science, vol. 13, pp. 442-455, 2002.

[10] D. Charles, et al., "Adoption of Electronic Health Record Systems among U.S. Non-federal Acute Care Hospitals: 2008-2013," Office of the National Coordinator for Health Information Technology, Washington, DC2014.

[11] W. M. Cohen and D. A. Levinthal, "Absorptive capacity: A new perspective on learning and innovation," Administrative Science Quarterly, vol. 35, pp. 128-152, 1990.

[12] N. Connell and T. Young, "Evaluating healthcare information systems through an "enterprise" perspective," Information \& Management, vol. 44, pp. 433-440, 2007.

[13] J. Corrigan, "Crossing the quality chasm," in Building a Better Delivery System, ed Washington, DC: National Academy Press, 2005.

[14] C. M. DesRoches and P. D. Miralles, "Meaningful Use of Health Information Technology: What Does it Mean for Practicing Physicians?," in Electronic Medical Records: A Practical Guide for Primary Care, N. S. Skolnik, Ed., ed New York, NY: Humana Press, 2011, pp. 1-14.

[15] B. Doolin and L. McLeod, "Sociomateriality and boundary objects in information systems development," European Journal of Information Systems, vol. 21, pp. 570586, 2012.

[16] D. Dougherty, "Interpretive barriers to successful product innovation in large firms," Organization Science, vol. 3, pp. 179-202, 1992.

[17] M. B. Dunn and C. Jones, "Institutional logics and institutional pluralism: The contestation of care and science logics in medical education, 1967-2005," Administrative Science Quarterly, vol. 55, pp. 114-149, 2010.

[18] K. Eisenhardt, "Building Theories from Case Study Research," Academy of Management Review, vol. 14, pp. 532-550, 1989.

[19] C. Farr. (2016, July 19) How this technology is making doctors hate their jobs. FastCompany.

[20] L. Fleming and D. M. Waguespack, "Brokerage, boundary spanning, and leadership in open innovation communities," Organization Science, vol. 18, pp. 165-180, 2007.

[21] U. Gal, et al., "The dynamics of IT boundary objects, information infrastructures, and organisational identities: The introduction of 3D modelling technologies into the architecture, engineering, and construction industry," European Journal of Information Systems, vol. 17, pp. 290304, 2008.
[22] GAO, "21st Century Challenges: Reexamining the Base of the Federal Government," U.S. Government Accountability Office, Washington, DC2005.

[23] D. Garets and M. Davis, Electronic Medical Records vs. Electronic Health Records: Yes, There Is a Difference. Chicago, IL: HIMSS Analytics, 2006.

[24] A. Giddens, The Constitution of Society. Cambridge, UK: Polity Press, 1984.

[25] B. G. Glaser and A. L. Strauss, Discovery of Grounded Theory: Strategies for Qualitative Research. Chicago, IL: Aldine Publishing Company, 1967.

[26] A. Gopal and S. Gosain, "The role of organizational controls and boundary spanning in software development outsourcing: Implications for project performance," Information Systems Research, vol. 21, pp. 960-982, 2010.

[27] S. Gosain, "Enterprise information systems as objects and carriers of institutional forces: The new iron cage?," Journal of the Association for Information Systems, vol. 5, pp. 151-182, 2004.

[28] N. Hayes, "Boundless and bounded interactions in the knowledge work process: The role of groupware technologies," Information and Organization, vol. 11, pp. 79101, 2001.

[29] K. Häyrinen, et al., "Definition, structure, content, use and impacts of electronic health records: a review of the research literature," International Journal of Medical Iinformatics, vol. 77, pp. 291-304, 2008.

[30] R. Hillestad, et al., "Can electronic medical record systems transform health care? Potential health benefits, savings, and costs," Health Affairs, vol. 24, pp. 1103-1117, 2005.

[31] IoM, "Crossing the Quality Chasm: A New Health System for the 21st Century," Committee on Quality of Health Care in America, Institute of Medicine, Washington, DC2001.

[32] K. Jonsson, et al., "Turn to the material: Remote diagnostics systems and new forms of boundary-spanning," Information and Organization, vol. 19, pp. 233-252, 2009.

[33] H. Karsten, et al., "Crossing boundaries and conscripting participation: Representing and integrating knowledge in a paper machinery project," European Journal of Information Systems, vol. 10, pp. 89-98, 2001.

[34] K. C. Kellogg, et al., "Life in the trading zone: Structuring coordination across boundaries in postbureaucratic organizations," Organization Science, vol. 17, pp. 22-44, 2006.

[35] J. King, et al., "Clinical benefits of electronic health record use: National findings," Health Services Research, vol. 49, pp. 392-404, 2014. 
[36] B. Kogut and U. Zander, "Knowledge of the firm, combinative capabilities, and the replication of technology," Organization Science, vol. 3, pp. 383-397, 1992.

[37] R. Leifer and A. Delbecq, "Organizational/ environmental interchange: A model of boundary spanning activity," Academy of Management Review, vol. 3, pp. 40-50, 1978.

[38] N. Levina and E. Vaast, "The emergence of boundary spanning competence in practice: Implications for implementation and use of information systems," MIS Quarterly, vol. 29, pp. 335-363, 2005.

[39] N. Levina and E. Vaast, "Turning a community into a market: A practice perspective on information technology use in boundary spanning," Journal of Management Information Systems, vol. 22, pp. 13-37, 2006.

[40] R. Lindgren, et al., "Multi-contextuality in boundaryspanning practices," Information Systems Journal, vol. 18, pp. 641-661, 2008.

[41] A. Majchrzak, et al., "Transcending knowledge differences in cross-functional teams," Organization Science, vol. 23, pp. 951-970, 2012.

[42] J. G. March and H. A. Simon, Organizations. New York, NY: Wiley, 1958.

[43] N. Menachemi and R. G. Brooks, "Reviewing the benefits and costs of electronic health records and associated patient safety technologies," Journal of Medical Systems, vol. 30, pp. 159-168, 2006.

[44] R. H. Miller and I. Sim, "Physicians' use of electronic medical records: Barriers and solutions," Health Affairs, vol. 23, pp. 116-126, 2004.

[45] I. Nonaka, "A dynamic theory of organizational knowledge creation," Organization Science, vol. 5, pp. 1437, 1994.

[46] C. Noy, "Sampling knowledge: The hermeneutics of snowball sampling in qualitative research," International Journal of Social Research Methodology, vol. 11, pp. 327344, 2008.

[47] ONCHIT, "Adoption of Electronic Health Record Systems among U.S. Non-Federal Acute Care Hospitals: 2008-2015," Office of the National Coordinator for Health IT, Washington, DC2016.

[48] W. J. Orlikowski, "Knowing in practice: Enacting a collective capability in distributed organizing," Organization Science, vol. 13, pp. 249-273, 2002.

[49] S. D. Pawlowski and D. Robey, "Bridging user organizations: Knowledge brokering and the work of information technology professionals," MIS Quarterly, vol. 28, pp. 645-672, 2004.
[50] A. W. Richter, et al., "Boundary spanners' identification, intergroup contact, and effective intergroup relations," Academy of Management Journal, vol. 49, pp. 1252-1269, 2006.

[51] C. Rosenkranz, et al., "Boundary interactions and motors of change in requirements elicitation: a dynamic perspective on knowledge sharing," Journal of the Association for Information Systems, vol. 15, pp. 306-345, 2014.

[52] E. H. Shortliffe, "The evolution of electronic medical records," Academic Medicine, vol. 74, pp. 414-419, 1999.

[53] S. L. Star, "The structure of ill-structured solutions: Boundary objects and heterogeneous distributed problem solving," in Readings in Distributed Artificial Intelligence, M. Huhns and L. Gasser, Eds., ed Menlo Park, CA: Kaufman, 1988, pp. 37-54.

[54] S. L. Star and J. R. Griesemer, "Institutional ecology, translations' and boundary objects: Amateurs and professionals in Berkeley's Museum of Vertebrate Zoology, 1907-39," Social Studies of Science, vol. 19, pp. 387-420, 1989.

[55] A. L. Strauss and J. Corbin, Basics of qualitative research: Grounded theory procedures and techniques. Newbury Park, CA: Sage, 1990.

[56] J. M. Sutherland, et al., "Getting past denial-the high cost of health care in the United States," New England Journal of Medicine, vol. 361, pp. 1227-1230, 2009.

[57] M. L. Tushman and T. J. Scanlan, "Boundary spanning individuals: Their role in information transfer and their antecedents," Academy of Management Journal, vol. 24, pp. 289-305, 1981.

[58] J. Varon and P. E. Marik, "Clinical information systems and the electronic medical record in the intensive care unit," Current Opinion in Critical Care, vol. 8, pp. 616-624, 2002.

[59] J. R. Vest and L. D. Gamm, "Health information exchange: Persistent challenges and new strategies," Journal of the American Medical Informatics Association, vol. 17, pp. 288-294, 2010.

[60] C. Zietsma and T. B. Lawrence, "Institutional work in the transformation of an organizational field: The interplay of boundary work and practice work," Administrative Science Quarterly, vol. 55, pp. 189-221, 2010.

[61] J. A. Zlabek, et al., "Early cost and safety benefits of an inpatient electronic health record," Journal of the American Medical Informatics Association, vol. 18, pp. 169-172, 2011. 